\title{
APLIKASI RESERVOIR SATURATION TOOL(RST) LOG PADA CASED HOLE WELL UNTUK EVALUASI KANDUNGAN HIDROKARBON DI CEKUNGAN KUTAI, KALIMANTAN TIMUR
}

\author{
Priyo Hutomo*, Yatini \\ Teknik Geofisika, Universitas Pembangunan Nasional "Veteran” Yogyakarta \\ SWK 104 Jl. Ringroad Utara Condong Catur 55283. \\ *Penulis Penanggungjawab. E-mail: priyohutomo@hotmail.com (Priyo Hutomo) \\ Telp: +62-823-5042-6303
}

\begin{abstract}
ABSTRAK
Kondisi fisik sumur yang telah diproduksi sangat sulit untuk dipantau seperti tingkat saturasi fluida akibat dilapisi casing(cased hole). Kombinasi log Density dan Neutron Porosity saja kurang efektif untuk kondisi tersebut. Pengaruh dari cased hole mengurangi sensitivitas log Density dan Neutron Porosity. Reservoir Saturation Tool(RST) log merupakan cased hole log memanfaatkan pulsa neutron untuk pengukuran saturasi dan jenis fluida pada formasi. Log ini sangat efektif untuk evaluasi kandungan fluida setelah diproduksi. Hasil evaluasi tersebut digunakan untuk membedakan lapisan masih atau sudah tidak prospek hidrokarbon. Log ini memanfaatkan log sigma untuk evaluasi fase fluida, carbon oxygen Ratio(COR) untuk evaluasi unsur utama fluida terutama rasio karbon terhadap oksigen, dan $\log$ saturasi untuk mengidentifikasi persentase lapisan produktif. Umumnya $\log R S T$ dilakukan di zona-zona produktif. Hasil interpretasi data log di Cekungan $\mathrm{Ku}-$ tai menunjukkan bahwa terdapat indikasi hidrokarbon di kedalaman 3760 - 3765 feet berupa Gas dan minyak telah berkurang hingga 30\% setelah diproduksi dan pada kedalaman 3766-3790 feet masih terdapat kandungan minyak sekitar $25 \%$ dan gas sekitar $10 \%$ dari total kandungan sebelum diproduksi.
\end{abstract}

Kata Kunci : Cased Hole; Reservoir Saturation Tool(RST) log; Neutron; Sigma log; Carbon 


\begin{abstract}
Produced well's physical properties like fluid saturation is hard to monitored because it has been cased. Combination of density and neutron porosity log isn't effective in this situation. Effect of casing in a well reduces density and neutron porosity log sensitivity. RST log is a cased hole log using neutron pulse to measure fluid saturation and phase of formation. It is effective for evaluating fluid content of produced well. Evaluation result are used to differentiate prospect or non-prospect hydrocarbon layer after produced. It's utilize sigma log for evaluating fluid phase, carbon oxygen ratio(COR) for evaluating fluid main content, and saturation log to identify percentage of productive layer. Generally RST log is ran in productive zone. Interpretation result in Kutai Basin showing hydrocarbon indication in depth 3760 - 3765 feet as gas and depleted oil till 30\% before, in depth 3766 3790 feet around $25 \%$ oil and around $10 \%$ gas of total content before produced.
\end{abstract}

Keywords: Cased Hole; Reservoir Saturation Tool log; Neutron; Sigma log; Carbon Oxygen

\section{Pendahuluan}

Hidrokarbon merupakan salah satu sumber daya alam komersil. Hidrokarbon terakumulasi pada batuan porous dan permeabel yang biasa disebut dengan batuan reservoir. Hidrokarbon merupakan energi fosil bersifat tidak terbarukan sehingga memiliki keterbatasan yaitu keterdapatannya tidak dapat bertahan lama jika dieksploitasi terus-menerus. Hidrokarbon juga memiliki kelebihan yaitu sumber energi hidrokarbon memiliki kalori tinggi dengan harga terjangkau sehingga lebih ekonomis dan efisien untuk pemanfaatannya, dan juga hidrokarbon dapat disimpan sehingga sumber daya ini dapat dipindahkan dari satu tempat ke tempat lain. Produksi minyak dan gas pada umumnya mengalami penurunan debit produksi tiap tahunnya, karena hidrokarbon bukan bahan bakar yang terbarukan sehingga tidak dapat mempertahankan kandungannya di bawah permukaan. Perlu adanya usaha dalam peningkatan debit produksi tersebut yaitu dengan melakukan recovery atau pembukaan zona produktif lainnya, namun sampai saat ini tantangannya adalah susah untuk membedakan kondisi zona di bawah permukaan. Manajemen reservoir yang tepat dan efektif menjadi kunci sukses untuk mempertahankan tingkat produksi. 
Cased hole logging merupakan teknik penilaian formasi untuk sumur yang telah dilapisi oleh casing, salah satu metodenya yaitu reservoir saturation tool (RST) log. Reservoir saturation tool umumnya dilakukan untuk mengevaluasi saturasi hidrokarbon yang telah menurun pada sumur yang telah dilapisi casing untuk memantau saturasi dari lapisan produktif pada satu sumur. Pada lapisan yang telah dilapisi casing umumnya pembacaan $\log$ sangat terganggu, namun $R S T$ mampu menghasilkan respon yang baik dengan memanfaatkan neutron. $R S T$ dipilih karena kelebihannya yaitu murah dan resolusi cukup baik untuk monitoring saturasi fluida, fase fluida, dan kandungan fluida pada suatu sumur (Hemmingway, 2015[6])

\section{Bahan dan metode}

\subsection{Geologi Regional}

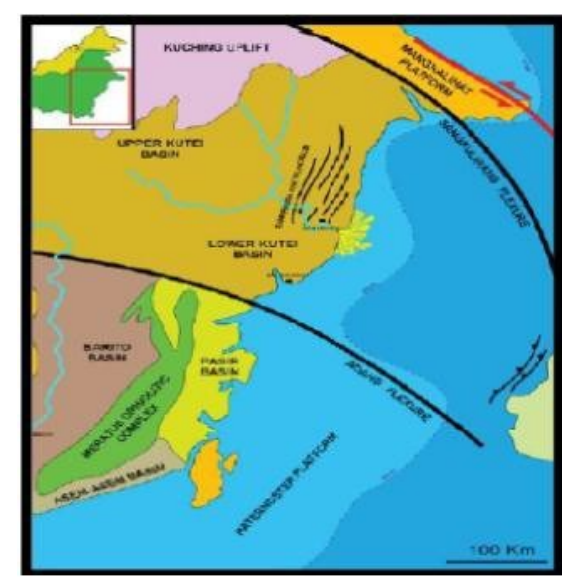

Gambar 1. Sketsa Fisiografi Regional Cekungan Kutai (Paterson, dkk., 1997)
Lokasi Penelitian terletak di

Cekungan Kutai memiliki luas \pm 60.000 km2 dan mengandung endapan Tersier dengan ketebalan mencapai $14 \mathrm{~km}$ (Rose dan Hartono, 1971 op.cit.Mora dkk.,2001). Cekungan Kutai terletak di tepi bagian timur dari Paparan Sunda, terbentuk akibat gaya ekstensi di bagian selatan Lempeng Eurasia (Howes, 1977 op.cit. Allen \& Chambers, 1998).

\subsection{Stratigrafi Cekungan Kutai}

Berdasarkan Peta Geologi Lembar Samarinda (Supriatna dkk., 1995[11]) stratigrafi Cekungan Kutai dibagi menjadi (dari tua ke muda): Formasi Pamaluan, Formasi Bebuluh, Formasi Pulau Balang, Formasi Balikpapan, Formasi Kampung Baru (Gambar 2.)

- Formasi Pamaluan

Batupasir kuarsa Sisipan Batulempung, Serpih, Batugamping dan Batulanau, berlapis sangat baik. Batupasir Kuarsa merupakan batuan utama, kelabu kehitaman - kecoklatan, berbutir halus - sedang, terpilah baik, butiran membulat - membulat tanggung, padat, karbonan dan gampingan. Setempat dijumpai struktur sedimen silang siur dan perlapisan sejajar. Tebal lapisan antara 1-2 m. Batulempung dengan ketebalan rata-rata 45 cm. Serpih, kelabu kehitaman - kelab tua, padat, dengan ketebalan sisipan antara $10-20 \mathrm{~cm}$. Batugamping 
berwarna kelabu, pejal, berbutir sedang- kasar, setempat berlapis dan mengandung foraminifera besar. Batulanau berwarna kelabu tua- kehitaman. Tebal Formasi lebih kurang $2000 \mathrm{~m}$

- Formasi Bebuluh

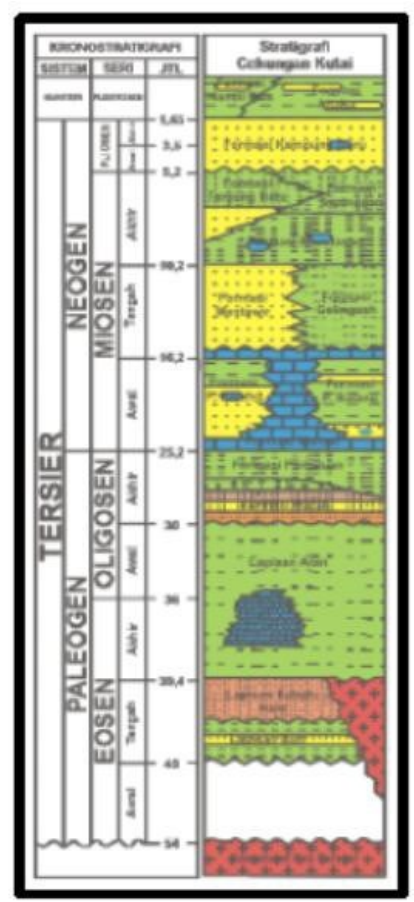

Gambar 2. Kolom Stratigrafi Regional Kalimantan Timur (Satyana dkk., 1995[10])

Batugamping Terumbu dengan Sisipan Batugamping Pasiran dan Serpih. Batugamping berwarna kelabu, padat, mengandung foraminifera besar, berbutir sedang. Setempat batugamping menghablur, terkekar tak beraturan. Serpih, kelabu kecoklatan berselingan dengan batupasir halus kelabu tua kehitaman. Tebal formasi sekitar $300 \mathrm{~m}$ diendapkan selaras di bawah formasi Pulau Balang.
- Formasi Pulau Balang

Perselingan Batupasir Greywacke dan Batupasir Kuarsa Sisipan Batugamping, Batulempung, Batubara dan Tuf Dasit. Batupasir Greywacke berwarna kelabu kehijauan, padat, tebal lapisan antara 50-100 $\mathrm{cm}$. Batupasir Kuarsa berwarna kelabu kemerahan, setempat tufan dan gampingan, tebal lapisan antara 15-60 cm. Batugamping berwarna coklat muda kekuningan, mengandung foraminifera besar. Batugamping ini terdapat sebagai sisipan atau lensa dalam Batupasir Kuarsa, ketebalan lapisan $10-40 \mathrm{~cm}$. Batulempung, kelabu kehitaman, tebal lapisan 1 - $2 \mathrm{~cm}$. Setempat berselingan dengan batubara, tebal ada yang mencapai $4 \mathrm{~m}$. Tufa dasit, putih merupakan sisipan dalam batupasir kuarsa.

- Formasi Balikpapan

Perselingan Batupasir dan Batulempung Sisipan Batulanau, Serpih, Batugamping dan Batubara. Batupasir Kuarsa, putih kekuningan, tebal lapisan 1 - 3 m, disisipi lapisan batubara, tebal 5-10 cm. Batupasir Gampingan, coklat, berstruktur sedimen lapisan sejajar dan silang siur, tebal lapisan 20-40 cm, mengandung foraminifera kecil disisipi lapisan tipis karbon. Batulempung, kelabu kehitaman, setempat mengandung 
sisa tumbuhan, oksida besi yang mengisi rekahan-rekahan, setempat mengandung lensa batupasir gampingan. Batulanau Gampingan, berlapis tipis, serpih kecoklatan, berlapis tipis. Batugamping Pasiran, mengandung foraminifera besar, moluska, menunjukkan umur Miosen Akhir bagian bawah - Miosen Tengah bagian atas, tebal formasi $1000-1500 \mathrm{~m}$.

- Formasi Kampung Baru

Batupasir Kuarsa dengan Sisipan Batulempung, Serpih, Batulanau dan Lignit, pada umumnya lunak, mudah hancur. Batupasir kuarsa, putih setempat kemerahan atau kekuningan, tidak berlapis, mudah hancur, setempat mengandung lapisan tipis oksida besi atau kongkresi, tufan atau lanauan, dan sisipan batupasir konglomeratan atau konglomerat dengan komponen kuarsa, kalsedon, serpih merah dan lempung, diameter $0,5-1 \mathrm{~cm}$, mudah lepas. Batulempung, kelabu kehitaman mengandung sisa tumbuhan, kepingan batubara, koral. Batulanau, kelabu tua, menyerpih, laminasi. Lignit, tebal $1-2 \mathrm{~m}$. Diduga berumur Miosen Akhir - Plioplistosen, lingkungan pengendapan delta - laut dangkal, tebal lebih dari $500 \mathrm{~m}$. Formasi ini menindih selaras dan setempat tidak selaras terhadap Formasi Balikpapan.
- Aluvium Kerikil,

Pasir dan lumpur diendapkan pada lingkungan sungai, rawa, delta, dan pantai.

\subsection{Thermal Decay Time log}

Thermal Decay Time log (TDT log) merupakan $\log$ yang merekam jumlah respon neutron kembali akibat penembakan dari sumber neutron terhadap formasi (Crain, 1999[4]). Besarnya elektron penembakkan dapat mencapai $14 \mathrm{MeV}$ (Mega elektron volt) seperti pada Gambar 3. Log ini biasa disebut pulsa neutron atau log waktu peluruhan neutron. Thermal Decay Time atau waktu paruh merupakan waktu untuk sejumlah neutron meluruh sampai $1 / \mathrm{e}$ atau hingga mencapai $37 \%$ dari jumlah asalnya. Waktu paruh neutron adalah waktu yang dibutuhkan agar awan neutron meluruh sampai setengah dari konsentrasinya. Parameter waktu paruh ini di peralatan dari perusahaan Schlumberger disebut "TAU".

\subsection{Reservoir Saturation Tool}

Reservoir Saturation Tool (RST) merupakan peralatan logging untuk penentuan saturasi fluida (Crain, 1999[4]). RST ini merupakan pengembangan dari TDT $\log$ dapat dilakukan secara open hole atau cased hole. Log ini memanfaatkan pulsa neutron seperti ditunjukkan pada Gambar 3. dimana 
dimana akuisisi sama seperti TDT $\log$, namun bedanya tidak hanya mengukur waktu paruh tapi juga melakukan komputasi untuk mendapat saturasi formasi. Cara kerja dari $R S T$ yaitu:

1. RST menghasilkan neutron yang dilepas ke dalam wellbore.

2. Neutron berinteraksi dengan peralatan logging, borehole, dan formasi.

3. Interaksi dari neutron pada inti atom yang dituju menyebabkan terpancarnya gamma ray dan terukur pada detektor.

4. Komputasi saturasi kemudian dilakukan oleh main unit dan menghasilkan satuan berupa jumlah neutron tertangkap c.u. (capture unit) dan persentase (\%) karbon dan oksigen.

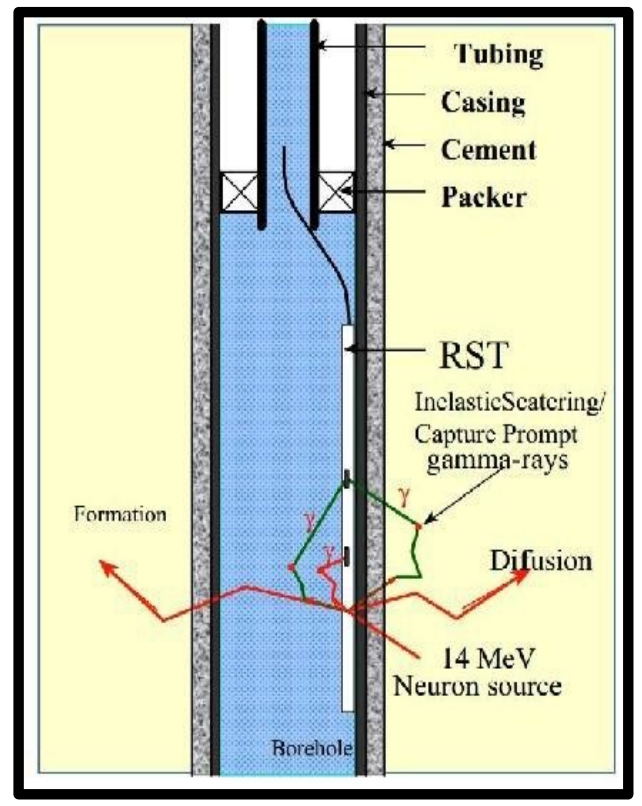

Gambar 3. Ilustrasi Pengukuran Reservoir Saturation Tool (Tanjung, 2016[12])
$R S T$ merupakan gabungan dari dua $\log$ yaitu carbon oxygen log dan pulsa neutron $\log$. Dua jenis $\log$ menunjukkan dua mode RST yaitu mode Sigma dan mode Inelastic (carbon oxygen mode). Log carbon oxygen (CO) digunakan untuk penentuan saturasi dari hidrokarbon pada formasi, kalkulasi dari salinitas air pada formasi mempengaruhi pembacaan semakin rendah kandungan salinitas maka semakin baik. Pada sistemnya terdapat dua detektor yaitu detektor far (jarak jauh) dan detektor near (jarak dekat).

$R S T \log$ ini dapat diterapkan untuk beberapa hal berikut :

- Rasio volume minyak formasi dari rasio $C / O$, tanpa mempertimbangkan salinitas air.

- Menangkap jumlah unsur $\mathrm{H}, \mathrm{Cl}, \mathrm{Ca}$, $\mathrm{Si}, \mathrm{Fe}, \mathrm{S}, \mathrm{Gd}$, dan MG.

- Menangkap rasio dari $\mathrm{C}, \mathrm{O}, \mathrm{Si}, \mathrm{Ca}$, dan Fe.

- Tiga fase penahan lubang sumur.

- Salinitas lubang sumur.

- Evaluasi formasi setelah sumur dilapisi casing.

- Pengukuran sigma, porosity, dan carbon/oxygen sekali bersamaan di lubang sumur.

- Evaluasi saturasi air pada sumur tua dimana teknologi open hole log belum pernah di-run.

- Pengukuran kecepatan air dalam casing, untuk tes kondisi rongga pada semen. 


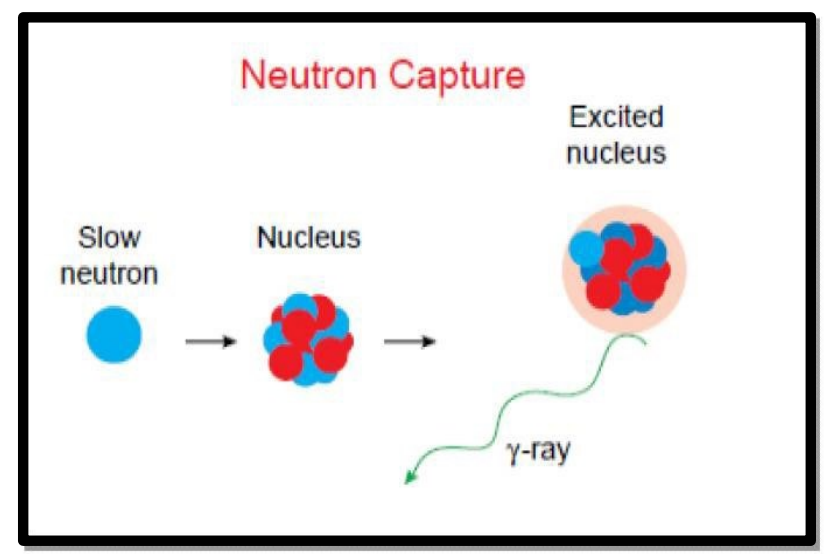

Gambar 4. Respon Neutron Terhadap Inti Batuan Pada Mode Sigma (Tanjung, 2016[12])

Kurva Sigma merupakan kalkulasi dari waktu paruh neutron (Crain, 1999[4]). Nilai terbaca di detektor adalah waktu paruh neutron, digunakan untuk perhitungan Sigma. Sigma menunjukkan kemampuan relatif material untuk menangkap atau menyerap neutron panas seperti diilustrasikan oleh Gambar 4. Sigma memiliki persamaan berikut ini :

$$
S I G M A=4550 / \mathrm{TAU}
$$

Keterangan :

SIGMA = banyaknya neutron tertangap (capture unit)

TAU = waktu paruh neutron ( $\mu \mathrm{sec})$
Disebut sigma karena didasari oleh kuantitas volumetrik dari komponen formasi (Tanjung, 2016[12]). Nilai dari RST sigma didapat dari respon neutron lambat yang ditembakkan dari sumbernya dan berinteraksi terhadap inti atom pada formasi, casing, dan semen, respon dari interaksi tersebut menghasilkan gamma ray.

Formasi diasumsikan sebagai sebuah kubus seperti ditunjukkan Gambar 5. dengan mengetahui nilai-nilai berikut ini:

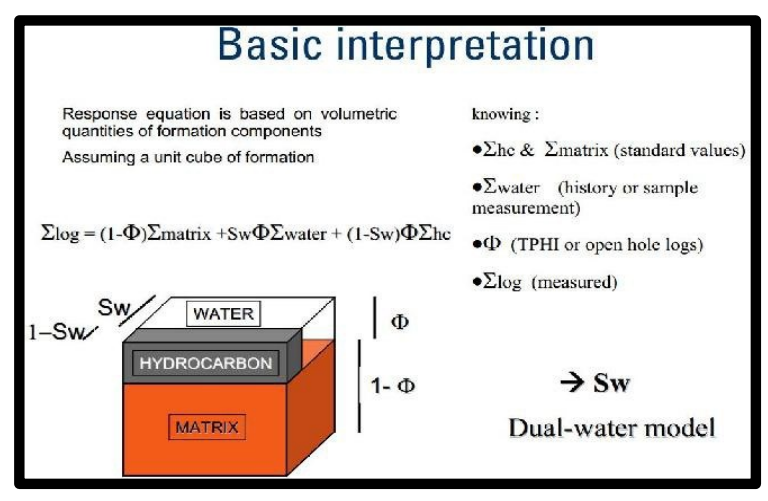

Gambar 5. Volumetrik Batuan Asumsi Sigma Model Dua Jenis Fluida (Tanjung, 2016[12]) 
- Persentase hidrokarbon dan matriks berdasar data logging sebelumnya atau coring.

- Persentase air berdasar data logging sebelumnya atau dari pengukuran sampel.

- Porositas berdasar TPHI yaitu log porosity hasil waktu peluruhan neutron atau data logging sebelumnya

Sigma log kemudian diukur dengan persamaan berikut ini :

$\sum \log =(1-\phi) \sum$ matrix + Sw $\phi \sum$ Water +

$$
(1-S w) \phi \sum \mathrm{hc}
$$

Keterangan :

$\begin{array}{ll}\sum_{\emptyset} \log & =\text { Sigma } \log (\mathrm{c} . \mathrm{u}) \\ \sum \text { matrix } & =\text { Sigma Persentase matriks }\end{array}$

Sw $\quad=$ Saturasi air $(\%)$

$\sum$ Water $=$ Sigma kandungan air

Shc $\quad=$ Sigma hidrokarbon
Schlumberger membuat klasifikasi fase fluida pada tabel 1. sesuai kalkulasi Sigma. Unsur dengan kemampuan menangkap neutron panas banyak umumnya adalah chl orine $(\mathrm{Cl})$ di alam dan sebaliknya unsur dengan kemampuan menangkap neutron panas sedikit adalah $h i$ drogen $(\mathrm{H})$, oleh karena itu $\log$ ini sangat sensitif terhadap tingkat salinitas sumur. Unsur hidrogen banyak dijumpai pada kandungan fluida seperti air, hidrokarbon, dan gas di dalam sumur, sedangkan unsur chlorine umumnya terdapat sebagai Sodium Chlorine atau $\mathrm{NaCl}$ yang terlarut di dalam air atau berupa suatu tubuh batuan.

\subsection{Inelastic Mode}

Inelastic (IC) mode merupakan mode yang umum digunakan untuk membedakan air dan minyak berdasar rasio dari Carbon Oxygen secara cased hole, mode ini juga biasa disebut mode rasio COR (Tanjung, $2016[12])$.

Tabel 1. Nilai Capture Unit Hasil Akuisisi RST Sigma (Tanjung, 2016[12])

\begin{tabular}{|c|c|c|}
\hline Material & Tau & $\begin{array}{c}\text { Computed } \\
\text { Sigma @20 C }\end{array}$ \\
\hline & ( $\mu \mathrm{sec})$ & (cu) \\
\hline Quartz $\left(\mathrm{SiO}_{2}\right)$ & 1070 & 4.25 \\
\hline Calcite $\left(\mathrm{CaCO}_{3}\right)$ & 630 & 7.2 \\
\hline Dolomite $\left(\mathrm{CaCO}_{3} \cdot \mathrm{MgCO}_{3}\right)$ & 944 & 4.8 \\
\hline Anhydrite $\left(\mathrm{CaSO}_{4}\right)$ & 367 & 12.4 \\
\hline Halite ( $\mathrm{NaCl})$ & 6.3 & 726.0 \\
\hline Iron & 23 & 198.0 \\
\hline Fresh Water $\left(\mathrm{H}_{2} \mathrm{O}\right)$ & 205 & 22.2 \\
\hline Salt Water & $152-35$ & $30-130$ \\
\hline Oil & 228 & 20 \\
\hline Gas & 910 & 5 \\
\hline Shale (approx) & $130-80$ & $35-55$ \\
\hline Hydrogen (approx) & 455 & 10 \\
\hline \multirow[t]{2}{*}{ Boron (approx) } & 0.2 & 20000 \\
\hline & & Apparent Sigma \\
\hline Sandstone & & $8.0-10.0$ \\
\hline Limestone & & 12.0 \\
\hline Dolomite & & 8.0 \\
\hline
\end{tabular}




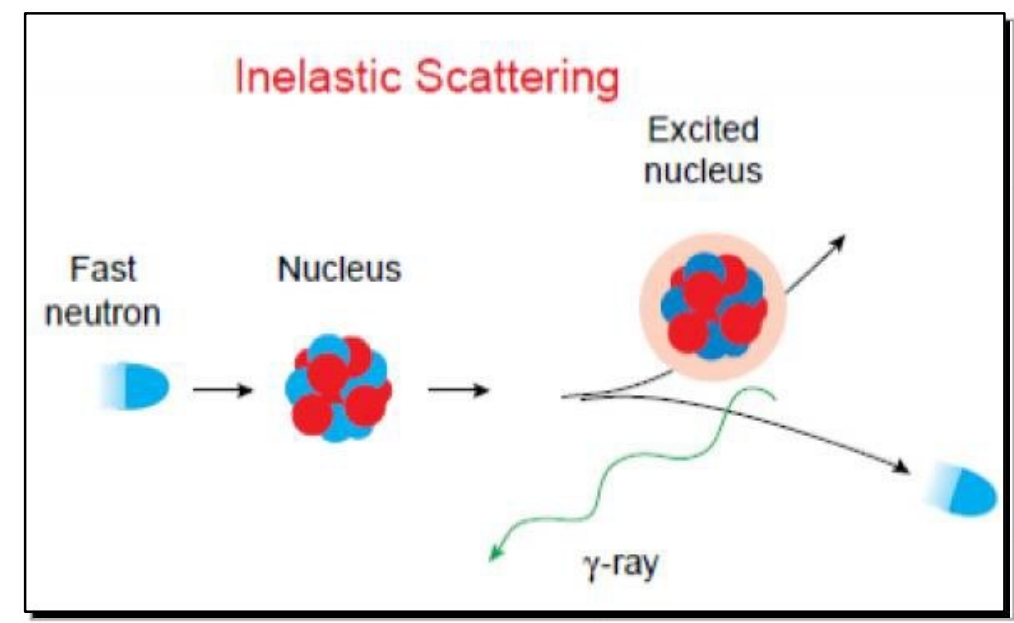

Tabel 1. Nilai Capture Unit Hasil Akuisisi RST Sigma (Tanjung, 2016[12])

Nilai dari RST IC mode didapat respon neutron cepat yang ditembakkan dari sumber dan berinteraksi terhadap inti atom pada formasi, casing, dan semen seperti ditunjukkan pada Gambar 6. Respon dari interaksi tersebut menghasilkan gamma ray dan neutron hasil penembakan terhadap inti atom. Log IC dipakai saat saturasi air dapat ditentukan serta untuk lapangan dengan salinitas rendah setelah diukur oleh Sigma log atau saat salinitas sumur bernilai tidak teratur.

Mode inelastic digunakan untuk :

- Memonitor saturasi air melalui tubing (pada kondisi sumur tertutup dan mengalir).

- Melokalisir aliran minyak.

- Mendeteksi aliran air.

- Memonitor kontak gas/minyak atau air/minyak.

- Menghitung kandungan unsur dan litologi.
Mode IC memanfaatkan hamburan neutron. Mode ini mengukur spektrum gamma ray yaitu perbedaan panjang dan frekuensi gelombang gamma ray, dengan kemampuan menembus sumur sampai 6 inci. Terkadang volume yang sedikit menunjukkan persentase pada lubang bor dan formasi. Kandungan karbon pada sumur terdapat di air, oksigen, dan matriks batuan ketiga hal tersebut sangat mempengaruhi nilai terukur. Sehingga perlu diperhatikan efek dari ketiga hal tersebut untuk memperkuat interpretasi.

\section{Hasil dan Pembahasan}

Gambar 7. menunjukkan data hasil olahan akuisisi RST yaitu porosity (TPHI), dan sigma, serta sejumlah data open hole log yaitu density bulk (RHOB), Caliper, dan neutron porosity (NPHI). Log Sigma menunjukkan 
respon pulsa neutron tertangkap hasil penembakan ke formasi, casing, dan semen. Log sigma menunjukkan beda fase fluida, dimana sigma bernilai rendah apabila fluida yang berinteraksi dengan neutron cenderung tidak memantulkan kembali neutron tersebut seperti gas akibat atom-atom yang lepas, sedangkan semakin kuat hubungan antara atom maka semakin neutron mampu memantul kembali seperti cairan. Pada penggunaannya $\log$ ini lebih baik untuk interpretasi fase gas, karena respon gas lebih jelas dimana capture unit bernilai sangat rendah pada saat terdapat kandungan gas pada pori- pori di formasi atau di sumur.

Log TPHI, Sigma, dan NPHI digunakan untuk mencari respon fase fluida. Pada Gambar 7. tampak bahwa repon sigma bernilai kecil pada kedalaman 3760 - 3785 feet. Kemudian pada kedalaman sama tampak terdapat persilangan antara $\log \mathrm{NPHI}$ dan RHOB dari open hole log yang menunjukkan pada kedalaman tersebut terdapat fluida dengan persilangan sangat besar. Log TPHI menunjukkan bahwa pada kedalaman tersebut nilai persilangan porosity (TPHI) setelah diproduksi lebih kecil daripada persilangan antara porosity dari open hole $\log$ yang besar, hal ini dapat disimpulkan bahwa telah terjadi pengurangan saturasi fluida yang diindikasikan sebagai respon dari gas setelah diproduksi dan sebelum diproduksi.

\subsection{Interpretasi Carbon Oxygen Ratio}

$\log$

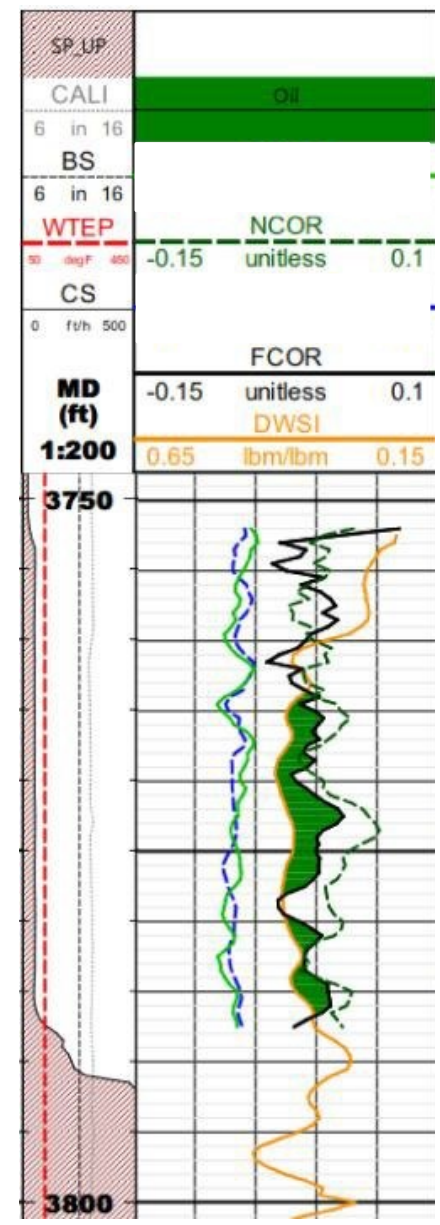

Gambar 8. Log Carbon oxygen Ratio

Gambar 8. menunjukkan data hasil pengolahan akuisisi $R S T$ yaitu, near carbon oxygen ratio (NCOR), far carbon oxygen ratio, (FCOR) dan dry weight silicon indicator (DWSI). Log NCOR dan FCOR didapat dari pembacaan nilai rasio carbon oxygen pada detektor near dan far. Semakin besar nilai FCOR atau NCOR 
maka semakin banyak unsur karbon terukur, sedangkan semakin kecil pembacaannya maka semakin banyak nilai oksigen terukur. Carbon oxygen log ini berguna untuk membedakan unsur fluida di sumur. Semakin banyak nilai oksigen maka dapat diidentifikasi semakin tinggi kandungan fluida non-hidrokarbon seperti air, sedangkan semakin tinggi kandungan karbon maka semakin tinggi kandungan fluida hidrokarbon yang diharap sebagai minyak. Log DWSI menunjukkan persentase kandungan silika yang mewakili tingkat "kebersihan" dari pasir. Nilai DWSI umumnya semakin besar pada batupasir bersih tanpa pengotor seperti kandungan mineral lempung.

Crossover dari nilai FCOR atau NCOR dan DWSI dapat digunakan untuk menunjukkan keberadaan fluida. Pada Gambar 8. pada saat FCOR atau NCOR dan DWSI bernilai besar maka dapat diindikasi pada kedalaman 3760 - 3785 feet terdapat fluida karena nilai rasio $\mathrm{C} / O$ cenderung lebih dari nilai lainnya maka fluida tersebut diindikasikan sebagai hidrokarbon. Pada Gambar 8. menggunakan FCOR dikarenakan detektor jauh lebih mampu merepresentasi kandungan fluida pada formasi.

\subsection{Interpretasi $\log$ Saturasi Fluida}

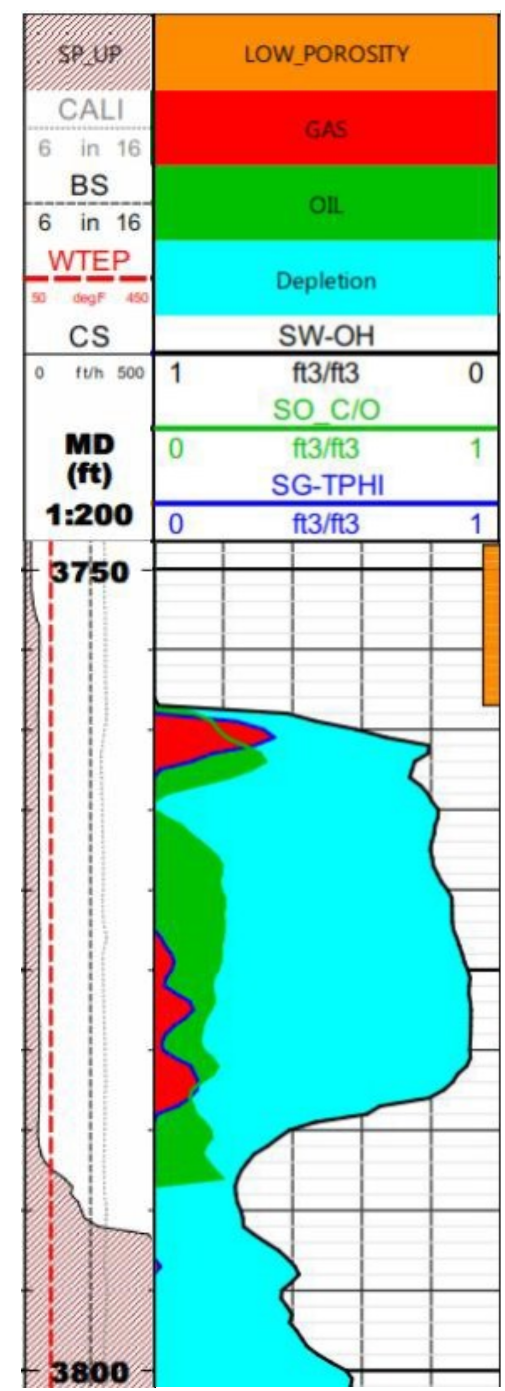

Gambar 9. Log Saturasi Fluida

Gambar 9. menunjukkan $\log$ saturasi fluida hasil analisa petrofisika log dimana terdapat log Saturation Water Open hole (SW-OH), Saturation Oil Carbon oxygen (SO_C/O), dan Saturation Gas TPHI (SG-TPHI). Log $\mathrm{SW}-\mathrm{OH}$ menunjukkan respon persentase fluida formasi yaitu air formasi sebelum zona produktif dibuka, semakin tinggi saturasinya maka semakin tinggi 
kandungan air. Pada $\log \mathrm{SW}-\mathrm{OH}$ ditunjukkan persentase sisa dari saturasi air berwarna biru yang menunjukkan persentase hidrokarbon awal. $\log \mathrm{SO} C / O$ menunjukkan persentase hidrokarbon berupa saturasi minyak tersisa setelah diproduksi didapat dari hasil evaluasi ulang menggunakan $R S T$. $\log S O \quad C / O$ didapat dari nilai perhitungan kandungan saturasi menggunakan log carbon oxygen. LOG SG-TPHI menunjukkan persentase dari kandungan gas menggunakan log TPHI sebagai basis porositasnya. Pada $\log$ ini juga terdapat sejumlah daerah berporositas rendah, namun belum terindikasi kandungan fluida di dalamnya.

Pada Gambar 9. $\log$ saturasi fluida menunjukkan kandungan fluida secara kuantitatif. Log saturasi fluida ini hanya dilakukan tiap formasi produktif karena sudah terindikasinya kandungan fluida sebelumnya. Pada kedalaman 3760-3765 feet tampak bahwa terdapat indikasi hidrokarbon berupa gas dan minyak yang telah berkurang hingga $30 \%$ dari awal sebelum diproduksi, kemudian pada kedalaman 3766-3790 feet tampak bahwa masih terdapat kandungan minyak sekitar $25 \%$ dan gas sekitar $10 \%$ dari total kandungan sebelum diproduksi

\section{Simpulan}

Kegiatan akuisisi RST ini sangat penting untuk mengevaluasi lapisan produksi untuk pembukaan lapisan prospek hidrokarbon berikutnya, dari semua pembahasan yang ada dapat disimpulkan secara garis besar sebagai berikut :

1. Pada akuisisi $R S T$ ini terdapat tiga log penting yang digunakan untuk evaluasi saturasi fluida hidrokarbon dalam sumur yaitu log sigma untuk evaluasi fase fluida, log carbon oxygen ratio untuk evaluasi unsur utama fluida, dan $\log$ saturasi untuk mengetahui persentase lapisan produktif setelah diproduksi.

2. Log RST dilakukan pada zonazona atau lapisan produktif saja karena tujuannya untuk evaluasi ulang saturasi hidrokarbon formasi.

3. Pada kedalaman 3760-3765 feet terdapat indikasi hidrokarbon berupa gas dan minyak yang telah berkurang hingga 30\% dari awal sebelum diproduksi, pada kedalaman 3766-3790 feet masih terdapat kandungan minyak seki$\operatorname{tar} 25 \%$ dan gas sekitar $10 \%$ dari total kandungan sebelum diproduksi. 


\section{Ucapan Terima Kasih}

Penulis sangat berterimakasih kepada Ibu Dr. Yatini selaku dosen pembimbing dan semua pihak yang mendukung pembuatan paper ini.

\section{Referensi}

1. Alberty, Mark W. 1993. Mtds $10-$ Development Geology Reference Manual. AAPG.

2. Allen, G.P., Chambers, John L.C. 1998. Sedimentation of The Modern and Miocene Mahakam Delta. Indonesian Petroleum Assosiation, Jakarta.

3. Chambers, John L.C., Moss, Steve J. 2000. Depositional Modeling and Facies Architecture of Rift and Inversion Episodes in The Kutai Basin, Kalimantan Indonesia. Proceeding of the Fourth Annual Convention, XXVII, Indonesian Petroleum Association, 467486, Jakarta.

4. Crain, E.R., P.Eng. 1999. Crain's Petrophysical Handbook.

5. Hearst, J.R., Nelson, P.H., and Paillet, F.L. 2000. Well Logging for Physical Properties, second edition. New York City: John Wiley \& Sons.

6. Hemmingway, James. 2015. Formation Evaluation Using Measurements made Through Casing. Society of Petreleum
Engineers Distinguish Lecturer

Program.

7. Paterson, D.W., Bachtiar, A., Bates, J.A., Moon, J.A., Surdam, R.C., 1997. Petroleum System of the Kutai Basin, Kalimantan, Indonesia, Petroleum System of SE Asia Australia Conference, May 1997. Proceedings Indonesia Petroleum Association, Jakarta, p: 711 -713

8. Plasek, R.E. 1995. Improved Pulsed Neutron Capture Logging With Slim Carbon-Oxygen Tools: Methodology. Society of Petroleum Engineers.

9. Roscoe, B.A., dkk. 1991. A New Through-Tubing Oil-Saturation Measurement System. Society of Petroleum Engineers.

10. Satyana, A.H., Nugroho, D., Surontoko, I., 1999, Tectonic Controls On The Hydrocarbon Habitats Of The Barito, Kutai And Tarakan Basin, EastnKalimantan, Indonesia, Journal Of Asian Earth Sciences Special Issue Volume 17, hal 99 - 122.

11. Supriatna, S., Sudrajat, A., Abidin, H.Z., 1995. Geological Map of the Muara Tewe Quadrangle, Kalimantan, Geological Research and Development Centre, Bandung.

12.Tanjung, Heri \& Aulia Carolina. 2016. Cased Hole Formation Evaluation in Badak-204 and Badak172 using RST Sigma and C/O Log. Jakarta: Schlumberger. 